\title{
Kemampuan Literasi Matematis Siswa pada Pembelajaran Model Problem Based Learning (PBL)
}

\author{
Heka M. Tabun ${ }^{1}$, Prida N. L. Taneo ${ }^{2}$, Farida Daniel ${ }^{3}$ \\ 1,2,3Program Studi Pendidikan Matematika, STKIP Soe \\ E-mail: heckatabun@gmail.com ${ }^{1}$, stafpridataneo@ stkipsoe.ac.id ${ }^{2}$, staffaridaniel@stkipsoe.ac.id ${ }^{3}$
}

\begin{abstract}
Abstrak
Kemampuan literasi matematis siswa sangat penting dalam proses pembelajaran matematika. Kurangnya kemampuan literasi matematis menjadikan kemampuan siswa dalam bernalar, berargumen dan berkreasi tidak berkembang sehingga sulit menyelesaikan persoalan matematika dalam kehidupan sehari-hari. Analisis hasil kerja siswa SMP Kristen 1 Mollo Selatan menunjukkan bahwa kemampuan literasi matematis siswa masih rendah.Penyebabnya adalah soal yang digunakan sebagai latihan dan tugas rumah merupakan soal-soal rutin dan kurang dikaitkan dengan kehidupan nyata. Salah satu upaya yang dilakukan untuk mengatasi permasalahan ini adalah dengan menerapkan model Problem Based Learning (PBL). Tujuan penelitian ini adalah untuk menghasilkan kajian tentang kemampuan literasi matematis siswa pada kelas dengan pembelajaran model PBL dan kelas yang tidak mendapat pembelajaran model PBL. Penelitian ini menggunakan metode kuantitatif model quasi eksperimen yang dirancang dalam bentuk nonequivalent control group design dengan melibatkan dua kelas penelitian yang ditentukan dengan teknik simple random sampling. Instrumen yang digunakan sebagai alat pengumpulan data adalah tes kemampuan literasi matematis siswa berupa soal uraian.Teknik analisis data dalam penelitian ini menggunakan uji t sampel independen. Hasil analisis menunjukkan bahwa kemampuan literasi matematis siswa pada kelas yang mendapat pembelajaran model PBL lebih baik dari kelas yang tidak mendapat pembelajaran model PBL. Peningkatan kemampuan literasi matematis siswa dengan pembelajaran model PBL berada pada kategori tinggi dengan rata-rata skor gain 0,8 .
\end{abstract}

Kata Kunci: kemampuan literasi matematis, model PBL.

\section{The Ability of Student' Math Literation on Learning Model Problem-Based Learning $(P B L)$}

\begin{abstract}
Students' ability to mathematical literacy is very important in their math learning process. Less ability of mathematical literacy as students' way of thinking, argumentation and creating is no improvement so they face difficulties in solving math problems in their learning process related to real life. The analysis of the result from students of SMP Kristen 1 Mollo Selatan shows that they are still a low inability of mathematical literacy. The effect is questions used as exercise are common questions and not related to real life. To solve this problem, the researcher implemented Problem Based Learning (PBL) as a teaching literacy to improve students' mathematical literacy abilities. This study will compare two classes in which one of them treated with PBL one of the other ones was not treated with PBL. A quasi-experiment quantitative method that used in this study with nonequivalent control group design. Two classes were selected as the sample by using simple random sampling. An essay test related to students' mathematical literacy ability was used as the instrument to collect the data. The analysis technique in this study was an independent sample t-test to the result showed that the class which was treated used the PBL method was better than the class which was not treated used the PBL method. Students' mathematical literacy ability in the PBL class was significantly proved in the high category with the score gain 0,8.
\end{abstract}

Keywords: mathematical literacy ability, PBL model. 


\section{PENDAHULUAN}

Matematika membekali siswa untuk memiliki kemampuan berpikir logis, analitis, sistematis, kritis serta kemampuan bekerjasama, sehingga perlu diberikan kepada semua siswa untuk setiap jenjang pendidikan dari tingkat dasar sampai perguruan tinggi. Tujuan pembelajaran matematika yang dirumuskan oleh National Council of Teachers of Mathematics/NCTM (2000:7) adalah siswa harus memiliki kemampuan: (1) komunikasi matematis, (2) penalaran matematis, (3) pemecahan masalah, (4) koneksi matematis, dan (5) representasi matematis. Tujuan pembelajaran matematika ini sudah sesuai dengan aspek pengembangan literasi matematis. Literasi matematis merupakan kemampuan seseorang untuk merumuskan, menerapkan dan menafsirkan matematika dalam berbagai konteks, termasuk kemampuan melakukan penalaran secara matematis, menggunakan konsep, prosedur, fakta dan alat bantu matematika untuk mendeskripsikan suatu fenomena atau kejadian (OECD, 2016).

Kemampuan literasi matematis ini sesuai dengan kemampuan-kemampuan matematis yang dinilai dalam Program for Internasional Student Assesment (PISA). Kemampuan matematis yang digunakan dalam penilaian PISA (OECD, 2016), yaitu: (1) komunikasi (communication), (2) matematisasi (mathematizing), (3) representasi (representation), (4) penalaran dan argumen (reasoning and argument), (5) merumuskan strategi untuk memecahkan masalah (devising strategis for solving problems), (6) menggunakan bahasa simbolik, formal dan teknik, serta operasi (using simbolic, formal and technical language and operations), (7) menggunakan alat-alat matematika (using mathematical tools). Kemampuan literasi matematis siswa sangat penting dalam proses pembelajaran matematika. Kurangnya kemampuan literasi matematis menjadikan kemampuan siswa dalam bernalar, berargumen dan berkreasi tidak berkembang sehingga sulit menyelesaikan persoalan matematika dalam kehidupan sehari-hari.

Survei yang dilakukan oleh PISA untuk mengukur kemampuan anak usia 15 tahun dalam literasi membaca, matematika dan sains pada tahun 2015, menempatkan Indonesia pada peringkat 63 dari 70 negara peserta survei. Skor yang diperoleh siswasiswa Indonesia khususnya kemampuan literasi matematis adalah 386.Skor ini berada jauh di bawah rata-rata yang ditetapkan yakni 490 (OECD, 2016).Hasil pencapaian ini menunjukkan kemampuan literasi matematis siswa-siswa Indonesia masih tergolong rendah.Literasi matematis siswa dalam PISA terbagi menjadi 6 tingkatan atau level. Literasi matematis level 1 dan level 2 merupakan kelompok soal dengan skala rendah, level 3 dan level 4 merupakan kelompok soal dengan skala menengah, sedangkan level 5 dan level 6 merupakan kelompok soal dengan skala tinggi (Jufri, 2015). Penilaian kemampuan literasi matematis dalam studi PISA dinilai berdasarkan level rendah sampai dengan level paling tinggi.

Studi PISA menunjukkan bahwa siswa-siswa Indonesia hanya mampu menyelesaikan soalsoal level 1 dan level 2 yaitu tingkatan yang masih mengacu pada soal-soal rutin. Hasil PISA yang rendah disebabkan oleh banyak faktor.Salah satu faktor penyebab adalah siswa pada umumnya hanya dibiasakan dengan mengerjakan 3 soal-soal rutin saja sehingga tidak terlatih dalam menyelesaikan soal yang berkarakteristik PISA (Linuhung, 2014).Hal ini diperkuat dengan hasil kerja siswa SMP Kristen 1 Mollo Selatan dalam menyelesaikan soal-soal yang berkarakteristik PISA.Hasil kerja siswa disajikan pada Gambar 1.

Gambar 1 menunjukkan bahwa siswa salah menafsirkan soal yang dikaitkan dengan kehidupan nyata sehingga strategi dan konsep yang diterapkan tidak tepat.Kesalahan siswa dilihat dari strategi yang digunakan yaitu dengan menerapkan konsep luas kubus sedangkan yang sebenarnya adalah menerapkan konsep volume.Hasil analisis kerja siswa ini menunjukkan bahwa siswa masih kesulitan menyelesaikan soal-soal nonrutin.

Observasi terhadap proses pembelajaran di kelas VII SMP Kristen 1 Mollo Selatan menunjukkan bahwa soal yang diberikan kepada siswa sebagai latihan atau tugas matematika merupakan soal-soal rutin dan kurang dikaitkan dengan kehidupan 4 nyata. Soal-soal seperti ini kurang mengembangkan aspek literasi matematis siswa.Selain itu aktivitas pembelajaran di kelas didominasi oleh guru dan kurang melibatkan siswa sehingga perlu perancangan pembelajaran yang banyak melibatkan siswa.Rancangan itu bisa dilakukan dengan menerapkan model, pendekatan dan metode pembelajaran yang tepat sehingga melibatkan siswa dalam pembelajaran. Solusi yang dapat mengatasi masalah tersebut adalah dengan menerapkan salah satu model pembelajaran yang dalam 
proses pembelajarannya menerapkankan masalahmasalah nyata agar pembelajaran tidak terkesan abstrak atau sulit serta tidak membiasakan siswa untuk mengerjakan soal-soal rutin saja. Salah satu alternatif untuk mengatasi permasalahan ini adalah dengan menerapkan model Problem Based Learning (PBL).

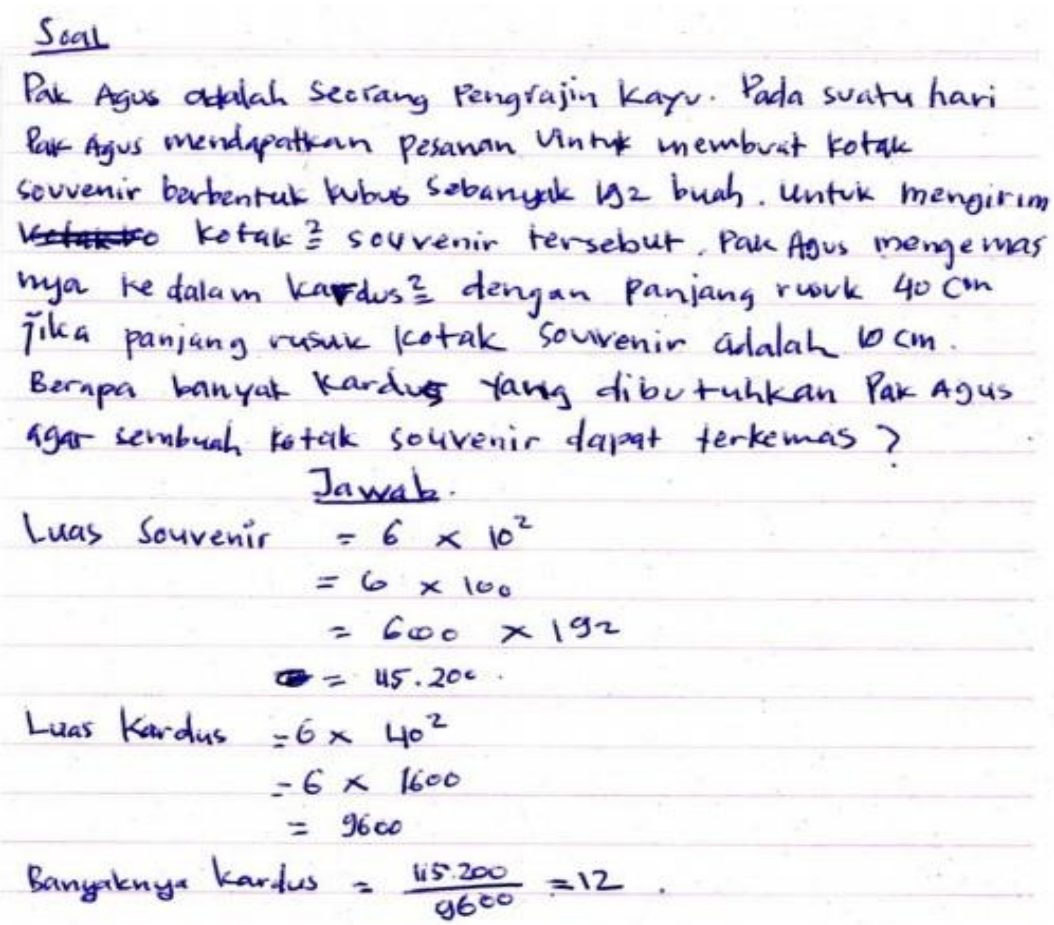

Gambar 1. Hasil Kerja Siswa

Model PBL merupakan sebuah model pembelajaran yang menerapkan masalah kontekstual sehingga merangsang siswa untuk belajar memecahkan masalah dunia nyata (Kemendikbud, 2013).Pembelajaran model PBL memiliki enam langkah yang disajikan dalam Tabel 1.

Tabel 1. Langkah-langkah Model PBL

\begin{tabular}{cl}
\hline Fase & \multicolumn{1}{c}{ Peran Guru } \\
\hline Orientasi siswa kepada masalah & Guru menjelaskan tujuan pembelajaran, menjelaskan segala hal \\
& yang akan dibutuhkan, memotivasi siswa terlihat dalam aktivitas \\
& pemecahan masalah yang dipilihnya \\
& Guru membantu siswa mendefinisikan dan mengorganisasikan \\
Mengorganisasi siswa untuk belajar & tugas belajar yang berhubungan dengan masalah
\end{tabular}

Membimbing penyelidikan individual maupun kelompok

Mengembangkan dan menyajikan hasil karya

Menganalisis dan mengevaluasi proses pemecahan masalah
Guru mendorong siswa untuk mengumpulkan informasi yang sesuai, melaksanakan eksperimen atau pengamatan untuk mendapatkan penjelasan dan pemecahan masalah Guru membantu siswa dalam merencanakan dan menyiapkan karya yang sesuai, melaksanakan eksperimen atau pengamatan untuk mendapatkan penjelasan dan pemecahan masalah

Guru membantu siswa untuk melakukan refleksi atau evaluasi terhadap penyelidikan mereka dan proses-proses yang mereka gunakan

(Hamdayama, 2014: 212)

Hasil kajian teoritis yang dikemukakan oleh Widyaswara dan Pertiwi (2017) menyimpulkan bahwa model PBL dapat digunakan untuk melatih literasi matematis karena memfasilitasi siswa 
untuk melakukan penyelidikan autentik dalam menyelesaikan masalah nyata.Penelitian Hidayat, Roza dan Murni (2018) menyatakan bahwa model PBL dapat meningkatkan kemampuan literasi karena dalam PBL kemampuan berpikir siswa dioptimalisasikan melalui proses kerja kelompok atau tim yang sistematis.. Hasil penelitian Pamungkas dan Pranita () jugamenyimpulkan bahwa pembelajaran matematika menggunakan PBL dapat meningkatkankemampuan literasi matematis siswa.Berdasarkan uraian di atas maka tujuan penelitian ini adalah untuk mengetahui perbedaan kemampuan literasi matematis siswa pada kelas dengan pembelajaran model PBL dan kelas dengan pembelajaran tanpa model PBL. Penelitian ini dilaksanakan di SMP Kristen 1 Mollo Selatan, kelas VIII tahun ajaran 2017/2018 materi teorema pythagoras dengan soal literasi matematis level 3.

\section{METODE}

Metode penelitian yang digunakan adalah metode kuantitatif dengan rancangan quasi eksperimen jenis nonequivalent control group design seperti pada Gambar 2.

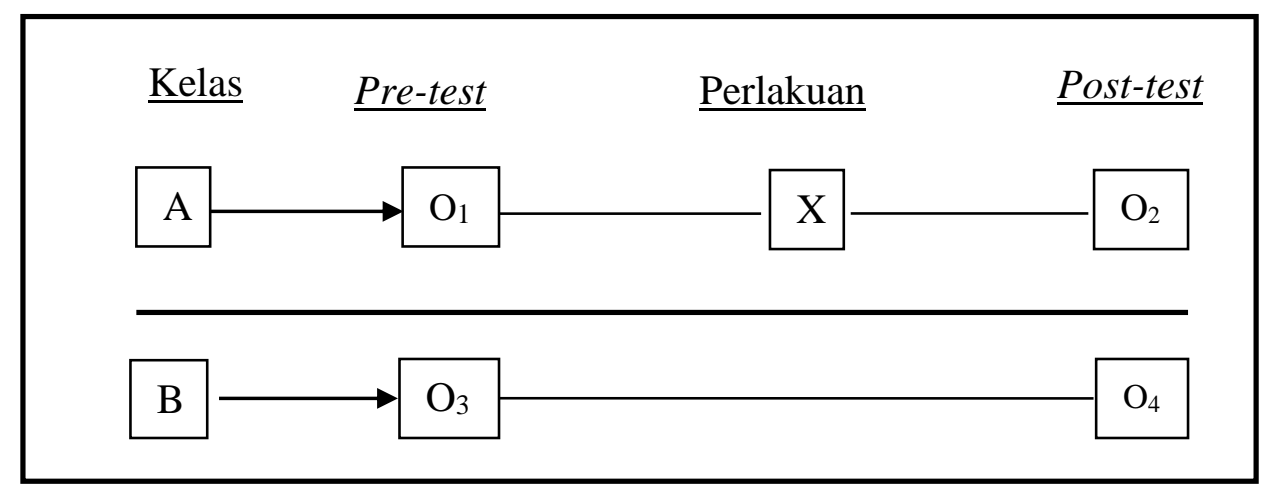

Gambar 2. Rancangan Quasi Eksperimen Jenis Nonequivalent Control Group Design

Desain penelitian melibatkan dua kelas sampel, yaitu kelas eksperimen (A) dan kelas kontrol (B). Kedua kelas diberi pre-test $\left(\mathrm{O}_{1}\right.$ dan $\left.\mathrm{O}_{3}\right)$ untuk mengetahui kemampuan awal siswa.Kelas eksperimen dikenai perlakuan/treatment $(\mathrm{X})$ yakni pembelajaran dilaksanakan dengan menggunakan model PBL sedangkan kelas kontrol dilaksanakan pembelajaran seperti biasa tanpa menggunakan model PBL. Pada akhir pembelajaran, dilaksanakan post-test bagi siswa pada kedua kelas $\left(\mathrm{O}_{2}\right.$ dan $\left.\mathrm{O}_{4}\right)$ untuk mengetahui kemampuan literasi matematis siswa.Populasi penelitian ini adalah seluruh siswa kelas VIII SMP Kristen 1 Mollo Selatan sebanyak tiga kelas dan sampelnya terdiri dari dua kelas yaitu kelas VIII A sebagai kelas eksperimen dan kelas VIII B sebagai kelas kontrol yang ditentukan menggunakan teknik simple random sampling.Instrumen pada penelitian ini adalah tes kemampuan literasi matematis siswa berupa soal uraian yang disusun berdasarkan indikator kemampuan literasi matematis siswa.Teknik analisis data yang digunakan adalah uji normalitas dan uji homogenitas sebagai uji prasyarat, kemudian dilanjutkan dengan uji t sampel independen dan skor gain.

\section{HASIL DAN PEMBAHASAN}

Materi pembelajaran yang diajarkan kepada siswa pada kelas eksperimen dan kontrol selama penelitian adalah penggunaan teorema phytagoras dalam pemecahan masalah yang didesain kedalam 3 pertemuan. Kegiatan pembelajaran di kelas eksperimen sesuai dengan langkah-langkah model PBL yaitu: (1) orientasi siswa kepada masalah, (2) mengorganisasi siswa untuk belajar, (3) membimbing penyelidikan individual maupun kelompok, (4) mengembangkan dan menyajikan hasil karya dan (5) menganalisis dan mengevaluasi proses pemecahan masalah.

\section{Orientasi siswa kepada masalah}

Pada tahap ini guru memberikan kesempatan kepada siswa untuk memahami masalah kontekstual yang berkaitan dengan teorema phytagoras yaitu bagaimana menghitung panjang sebuah tangga yang disandarkan pada sebuah tembok, mengukur tinggi dari tiang bendera, pohon maupun layang-layang 
serta menghitung lebar lapangan bola voly dan juga panjang kebun sesuai dengan unsur-unsur yang diketahui. Guru menjelaskan kepada siswa mengenai langkah-langkah menyelesaikan masalah dan memberikan kesempatan kepada siswa untuk bertanya jika ada hal-hal yang belum dipahami.

\section{Mengorganisasi siswa untuk belajar}

Pada tahap ini siswa dibagi kedalam 6 kelompok dimana setiap kelompok berjumlah 5 orang. Guru membimbing siswa dalam memecahkan masalah kontekstual dalam Lembar Kerja Siswa (LKS) yang dibagikan kepada siswa..

\section{Membimbing penyelidikan individual maupun kelompok}

Guru membimbing siswa mencari data atau referensi lain yang relevan dengan materi phytagoras melalui kegiatan pengamatan maupun eksperimen. Guru memberikan kesempatan kepada siswa untuk bertanya jika ada hal-hal yangbelum dipahami pada tahap ini.

\section{Mengembangkan dan menyajikan hasil karya}

Guru memberikan kesempatan kepada siswa untuk mempresentasikan hasil kerja kelompok mereka. Perwakilan setiap kelompok maju ke depan kelas untuk mempersentasikan hasil diskusi kelompoknya kemudian siswa dari kelompok lain menanggapi dengan cara menanyakan hal yang belum dipahami dari presentasi teman maupun melengkapi sesuai dengan hasil diskusi kelompoknya sendiri. Siswa dalam kelompok yang sama membantu menjawab pertanyaan dari kelompok lain. Setiap kelompok yang memiliki jawaban berbeda juga diberikan kesempatan untuk mempersentasikan jawabannya kemudian ditanggapi kelompok lain. Guru mengontrol dan mengarahkan siswa selama proses presentasi dan diskusi antar kelompok sampai semua siswa dalam kelompok memahami penyelesaian masalah yang ada.

\section{Menganalisis dan mengevaluasi proses pemecahan masalah}

Pada tahap ini guru membantu siswa melakukan analisis dan evaluasi terhadap hasil kerjanya. Guru membimbing siswa untuk melihat kembali hasil diskusi kelompok yang sudah dipresentasikan dan dibahas bersama sebelumnya kemudian melakukan evaluasi terhadap proses-proses penyelidikan dan langkah-langkah penyelesaian masalah yang mereka gunakan.

Kegiatan pembelajaran di kelas kontrol tidak menggunakan model PBL dimana metode yang diterapkan berupa ceramah dan pemberian tugas.Uraian kegiatan inti di kelas kontrol adalah guru menyampaikan materi tentang teorema phytagoras dan penggunaannya dalam pemecahan masalah kemudian memberikan kesempatan kepada siswa untuk bertanya jika ada hal-hal yang belum dipahami. Guru selanjutnya memberikan latihan kepada siswa dan mengoreksi hasil kerja siswa. Selanjutnya kegiatan diakhiri penarikan kesimpulan oleh siswa dengan dibimbing oleh guru dan pemberian tugas rumah bagi siswa.

Hasil tes kemampuan literasi matematis siswa sebelum dan setelah kegiatan pembelajaran di kedua kelas disajikan pada Tabel 2.

Tabel 2. Hasil Tes Kemampuan Literasi Matematis Siswa

\begin{tabular}{ccccc}
\hline \multirow{2}{*}{ Statistik } & \multicolumn{2}{c}{ Kelas Eksperimen } & \multicolumn{2}{c}{ Kelas Kontrol } \\
& Pre-test & Post-test & Pre-test & Post-test \\
\hline Skor maksimum & 59,57 & 100 & 63,83 & 74 \\
Skor minimum & 10,64 & 66 & 10,64 & 32 \\
Rata-rata & 43,48 & 86,87 & 47,52 & 52,73 \\
Simpangan baku & 16,22 & 8,75 & 12,13 & 11,44 \\
\hline
\end{tabular}

Tabel 2 menunjukkan bahwa kelas eksperimen dan kelas kontrol mengalami peningkatan kemampuan literasi matematis dengan hasil perolehan skor pre-test lebih rendah dari skor posttest.Peningkatan ini juga dilihat dari rata-rata kedua kelas dengan nilai rata-rata pre-test lebih rendah dari nilai rata-rata post-test. Simpangan baku data post-test kelas eksperimen lebih kecil dari 
simpangan baku kelas kontrol yang berarti bahwa kemampuan setiap siswa pada kelas eksperimen cenderung lebih homogen dibandingkan dengan kelas kontrol.

Analisis lanjutan dengan uji t-sampel independen menunjukkan bahwa $t_{\text {hitung }}=12,979>t_{\text {tabel }}=1,671$. Hasil analisis ini menunjukkan bahwa rataan kemampuan literasi matematis siswa pada kelas eksperimen lebih baik dari pada kelas kontrol. Analisis skor gain normalisasi juga menunjukkan bahwa adanya peningkatan 6 kemampuan literasi matematis siswa pada kelas eksperimen dengan kategori tinggi. Peningkatan ini dilihat dari perolehan skor gain normalisasi kelas eksperimen sebesar 0,8 sedangkan kelas kontrol sebesar 0,1. Hal ini sesuai dengan hasil penelitian yang dilakukan oleh Istiandaru, Wardono dan Mulyono (2014) yang menyimpulkan bahwa pembelajaran model PBL berpendekatan realistik saintifik dan asesmen PISA efektif meningkatkan kemampuan literasi matematika siswa. Hal serupa juga dikemukakan oleh Fitriono, Rochmad dan Wardono (2015) yang menyatakan bahwa penerapan model PBL dengan pendekatan PMRI berpenilaian PISA dapat meningkatkan kemampuan literasi matematis siswa.Penelitian Pamungkas dan Franita (2019) juga menyimpulkan bahwa pembelajaran matematika menggunakan PBL dapat meningkatkan kemampuan literasi matematis siswa.

Kemampuan literasi matematis siswa pada kelas eksperimen lebih baik dari kelas kontrol disebabkan karena pembelajaran model PBL menyajikan masalah kontekstual sehingga merangsang siswa untuk belajar memecahkan masalah-masalah dalam kehidupan nyata.Siswa diberikan kesempatan untuk memahami dan menyelesaikan masalah menghitung panjang sebuah tangga yang disandarkan pada sebuah tembok, mengukur tinggi dari tiang bendera, pohon maupun layang-layang serta menghitung lebar lapangan bola voly dan juga panjang kebun sesuai dengan unsur-unsur yang diketahui melalui penerapan teorema phytagoras.Permasalahan-permasalahan tersebut dekat dengan kehidupan sehari- hari siswa sehingga membuat siswa tidak merasa asing dan termotivasi untuk memecahkan masalah tersebut berdasarkan konsep matematika yang sudah dipelajarinya.Hal ini sejalan dengan Penelitian Istiandaru, Wardono dan Mulyono (2014) yang mengungkapkan bahwa kemampuan literasi matematis siswa dapat meningkat jika materi yang diajarkan langsung dikaitkan dengan kehidupan sehari-hari sehingga dapat menumbuhkan minat siswa untuk belajar. Gagne dalam teorinya juga menyatakan bahwa belajar matematika perlu dikaitkan dengan kehidupan nyata sehingga melatih siswa untuk mampu menyelidiki dan memecahkan masalah, belajar mandiri, bersikap positif terhadap matematika dan tahu bagaimana semestinya belajar (Suherman dkk, 2003:33-34).

Pembelajaran model PBL dimulai dengan menyajikan masalah-masalah matematika yang ada dalam dunia nyata sehingga menjadikan pembelajaran lebih bermakna.Siswa dituntut menggunakan pengetahuan matematikanya untuk memecahkan masalah kontekstual yang sering ditemuinya dilingkungan sekolah maupun di rumah.Pada tahap penyelidikan dalam kelompoknya siswa tidak hanya mengumpulkan informasi yang relevan di buku tetapi melakukan eksperimen seperti membuat sketsa/gambarmaupun mengamati langsung tiang bendera dan lapangan voly di sekolah sehinggadapat memperjelas masalah dan strategi pemecahannya. Hal ini sejalan dengan hasil penelitian Pratiwi dan Ramdhani (2017) yang menyatakan PBL terdiri dari menyajikan situasi masalah yang autentik dan bermakna sehingga dapat memberikan kemudahan kepada siswa untuk melakukan penyelidikan dan inkuiri.

Pembelajaran model PBL memberikan kesempatan kepada siswa untuk berdiskusi. Guru hanya berperan mengorganisasikan siswa untuk belajar dan membimbing penyelidikan sehingga siswa lebih leluasa dalam berbagi pemahamannya dengan teman dalam kelompok tanpa merasa canggung.Melalui proses bernalar, siswa berdiskusi untuk memperjelas masalah melalui pengamatan dan eksperimen serta bekerja samamengumpulkan informasi untuk menemukan dan melaksanakan strategi penyelesaian masalah. Siswa juga kemudian berbagi hasil kerja kelompoknya untuk mendapatkan tanggapan dari kelompok lain,Pembelajaran seperti ini melatih siswa untuk bebas mengungkapkan pengetahuannya dengan teman-temannya.Menurut Pertiwi dan Widyaswara (2017) dengan diskusi kelompok, siswa belajar untuk menghargai perbedaan pendapat untuk dapat memecahkan masalah.Untuk memperoleh solusi yang terbaik, berbagai pendapat tersebut didiskusikan dan diseleksi menggunakan pemikiran yang logis dengan memperhatikan hubungan antarunsur dalam masalah yang diberikan. Fitriono, dkk (2015) dalam penelitiannya menyatakan 
bahwa langkah-langkah model PBL memberikan kesempatan kepada siswa untuk berdiskusi dengan teman sebayanya sehingga memungkinkan siswa mudah memahami materi yang dipelajari.

Kemampuan literasi matematis siswa kelas eksperimen lebih baik dari kelas kontrol juga disebabkan karena siswa dibiasakan dengan mengerjakan soal-soal nonrutin yakni soal-soal PISA level 3. Pelaksanaan model PBL memfasilitasi siswa dalam mengembangkan kemampuan pemahaman konsep matematika, representasi matematika, penalaran matematika, komunikasi dan koneksi matematikaserta kemampuan pemecahan masalah kontekstual maupun soal-soal non rutin yang merupakan cakupan dari kemampuan literasi matematis.Siswa dituntut untuk menggunakan pengetahuannya dalam memahami masalah kemudian menyatakan masalah tersebut dalam model matematika maupun sketsa/gambar. Siswa juga didorong untuk bernalardalam menentukansolusi permasalahan melalui diskusi kelompok dan presentasi hasil diskusi sehingga membuat kemampuan literasinya meningkat.Hal ini sesuai dengan penelitian Sari dan Khyarunnisa (2017) yang menyimpulkan model PBL mampu meningkatkan kemampuan-kemampuan yang masuk ke dalam komponen kemampuan literasi matematka.Penelitian Fitriono, dkk (2015) juga menyatakan bahwa siswa mampu menyelesaikan soal-soal literasi matematis jika dalam proses pembelajaran, siswa dibiasakan dengan mengerjakan soal-soal literasi matematis mulai dari level rendah sampai pada level tertinggi.

\section{SIMPULAN}

Berdasarkan uraian di atas dapat disimpulkan bahwa kemampuan literasi matematis siswapada pembelajaran model PBL lebih baik dari siswa pada pembelajaran tanpa model PBL. Peningkatan kemampuan literasi matematis siswa pada kelas dengan pembelajaran model PBL berada pada kategori tinggi dengan perolehan skor gain 0,8 .

\section{DAFTAR PUSTAKA}

Fitriono, Y., Rochmad dan Wardono. (2015). Model PBL dengan Pendekatan PMRI Berpenilaian PISA untuk Meningkatkan Kemampuan Literasi Matematika Siswa.UJMER, 4(1):56-65.

Hamdayama.(2014). Model dan Metode Pembelajaran Kreatif dan Berkarakter. Bogor: Ghalia Indonesia.

Hidayat, R., Roza, Y. dan Murni, A. (2018).Peran Penerapan Model Problem Based Learning (PBL) terhadap Kemampuan Literasi Matematis dan Kemandirian Belajar.Juring (Journal for Research in Mathematics Learning), 1(3): 213-218.

Istiandaru, A., Wardono dan Mulyono. (2014). PBL Pendekatan Realistik Saintifik dan Asesmen PISA untuk Meningkatkan Kemampuan Literasi Matematika.UJMER, 3(2):1-8.

Jufri, L, H. (2015). Penerapan Double Loop Problem Solving untuk Meningkatkan Kemampuan Literasi Matematis Level 3 pada Siswa Kelas VIII SMPN 27 Bandung.LEMMA,2(1):1-11.

Kemendikbud.(2013). Materi Pelatihan Guru Matematika SMP/MTs tentang Implementasi Kurikulum 2013.

Linuhung, N. (2014). Pengaruh Strategi Pemecahan Masalah Wankat-Oreovocz dan Pembelajaran Teknik Probing terhadap Kemampuan Literasi Matematis SMP.Aksioma, 3(2):35-42.

National Council of Teachers of Mathematics/NCTM. (2000). Principles and Standards for School Mathematics. Reston, VA: National Council of Teachers of Mathematics.

OECD. (2016). PISA 2015 Assessment Framework: http://www.oecd.org. Diakses pada tanggal 22 Agustus 2017, jam 09.40 WITA. 
Pamungkas, M. D. dan Franita, Y. (2019). Keefektifan Problem Based Learning Untuk MeningkatkanKemampuan Literasi Matematis Siswa. Jurnal Penelitian Pendidikan dan Pengajaran Matematika, 5(2):75-80.

Pertiwi, R. D. dan Widyaswara, I. B. 2017.Enhancing Mathematical Communication Skill and Tolerance of Slow Learners in an Inclusive Classroom Using TSTS Model Assisted by Graphic Organizer, Proceeding KMP Education Research Conference.

Pratiwi, D. dan Ramdhani, S. (2017). Penerapan Model Problem Based Learning (PBL) untuk Meningkatkan Kemampuan Literasi Matematis Siswa SMK.JurnalGammath,2(2): 1-13.

Sari, M. P. dan Khiyarunnisa, A. (2017).Problem Based Learning: Upaya Meningkatkan Kemampuan Literasi Matematika Siswa. Prosiding Seminar Nasional Matematika dan Pendidikan Matematika, 11 November 2017: 443-448.

Suherman, H. E., dkk. (2003). Strategi Pembelajaran Matematika Kontemporer. Bandung: UPI

Widyaswara, I. B. dan Pertiwi, R. D. (2017).Melatih Literasi Matematis Siswa SMP Melalui ProblemBasedLearning Berbasis Budaya Rembang Berbantuan Edmodo.Prosiding Seminar Nasional Pendidikan Matematika Etnomatnesia, Program Studi Pendidikan Matematika, Universitas Sarjanawiyata Tamansiswa, 9 Desember 2017: 428-435. 